ト幅を選定するととか望ましく，今後の課題として遂次 研究を進めて行くつもりである.

\section{6）露出不足 X線写真の青色補力追試について} 福岡県立遠賀療養所 村橋 勝芳

機械の発達と技術の向上に上り, 露出不足のレ線写真 は余り出来なくなったが, ポータブル撮影或は交通事故 の急患，または胎児撮影等で再撮影の困難なもので露出 不足の写真が出来た場合，その処置に困るすのである。

所がそういう露出不足のレ線写真走簡単に読影可能な まで補力する方法が発表されているのを知り, 追試した 所非常な好結果を得たので報告し，で批判を抑ざたいと 思う。

補力方法は上村恵太郎氏発表（「写真と技術」X-レイ 通巻48号, 富士写真フィルム $\mathrm{KK}$ 発行) のもので, 既に 皆様で存知のととであり，今更述べるまでもないと思う が, 覑序として次に処方を示した。

\begin{tabular}{|c|c|}
\hline 過酸カリウム & $0.5 \mathrm{~g}$ \\
\hline 硫酸鉄アンモン（鉄明バン） & $1.5 \mathrm{~g}$ \\
\hline 苳 酸 & $3.0 \mathrm{~g}$ \\
\hline 赤血䍀 & $1.0 \mathrm{~g}$ \\
\hline アンモニウム明バン & $5.0 \mathrm{~g}$ \\
\hline 稀塩酸 & $1.0 \mathrm{cc}$ \\
\hline 水を加光て & $1,000 \mathrm{cc}$ \\
\hline
\end{tabular}

追試の結果, 大体 $1 / 3$ の撮影条件で撮影されたフィルム はこの補力方法により救われる．砳って胎児撮影等で露 出時間を短かくしておいて，乙の方法で補力すれば鮮鋭 度を落さずに然も被曝線量の軽娍にもなると思う。

\section{7） X線 TVについて}

$$
\text { 東芝玉川工場 }
$$

牧野 純夫

透視を明るい所で行ない，かつ放射線防護をよくし， 診断の精度を上げる方法として推進されて来たX線透視 のテレビ方式には種々のタイプが生れて来た。

(1) I.I. +ビデイコン方式

(2) I.I. +イメージオルシコン方式

(3) ミラーレンズ+オルシコン方式

(4) ミラーレンズ+ライトアンプ+オルシコン方式

(5) 蛍光板十オルシコン方式

上記 5 方式で最む普及している方式は(1)の方式で，(2) は(1)に比し像はよくなるが金額が大，(3)，(4)方式は今の 所材料が国産になく（5)特有のノイズが発生する等一 長一短がある.今後については全体として最む無理がな く, 安定に撮影が行なえるというととから, (1)の方式が 最も普及量が多くなると考える。
今後 TVは使いやすくより便利なものえとその方向を たどって行くであろうが，近時製品化されたX線 TV 装 置はややもすれば，防護と能率の二点に問題を絞りすぎ 診断の精度をなおざりにしていた観があり，私は精度が 向上する可能性を忘却してはならないと思う。

以上問題点を略記したが，その他の問題点についても 簡単に論じる.

8）透視スポット撮影に於けるカセッテの振動につい $\tau$

㑣生産業 $\mathrm{KK}$ 飯塚病院放射線科抖島昭 当病院で使用している I 型透視台（コンプレッサー式 速写装置付）によって撮影された胃の写真の鮮鋭度につ いて疑問を持ったので，I型透視台と】型透視台（手動 式速写装置付）のスポット撮影時のカセッテの振動につ いて比較実験した。実験方法は被写体に金網を使用して 撮影し，ミクロフォトメーターで光量を測定した。 その 結果 I 型透視台では固定撮影と比較して金網の縦軸・横 軸と屯特に縦軸の写真の光量曲線は比軟的ゆるやかでボ ケがあると瑟められた．【型逆視台ではそれが殆んど認 められなかった。

従ってI 型透視台での写真のボケは, コンプレッサー 式速写装置によるカセッテの振動に依るものと思われる. 当院使用の透視台に於ては手動式速写装置により自動的 に撮影出来るII型透視台の方が，良い結果が出たので報 告玄る。

\section{9) 200kV 高圧撮影装置について}

九大病院中央放射線部

○等佐美和男・觜巻 雅人・金丸 義孝

近年医療界の進歩と共に高圧撮影す盛んになったが， 今年の 5 月九大病院の一部中央化と共に使用して来たシ ーメンス社製トリドロス 4 特型の概要について報告する.

装置の主体をなずリリドロス 4 型は, 定格 $150 \mathrm{kV}, 300$ $\mathrm{mA}$ であるが，乙の 4 型トランスは更に補助トランスを 使用し， $50 \mathrm{kV}$ 昇圧して $200 \mathrm{kV}$ を得るようにした。

配電盤は(1)電源電圧の自動調整, (2)管球切替器, (3)電 流調整, (4)電圧調整, (5) mAs 調整（夕イマ一調整, 夕 イマ一目盛は 0.003〜8秒), (6)付属装置選択器, (7)透視 電圧・電流調整・透視タイマー, (8)Xレイスイッチ, (9) パイロットランプとなっている。

高圧発生装置はセレン整流体を内蔵，装置定格は 100 $\mathrm{kV}, 1,000 \mathrm{~mA}, 150 \mathrm{kV} 300 \mathrm{~mA}, 200 \mathrm{kV} 200 \mathrm{~mA}$ であり, X線管球は Pantix P200/30/50, 二重焦点管球である.

10）同時多層断層撮影に於ける截断面の検討 九大病院中央放射線部 